\title{
A Case in Support of Continuous Modeling for Stormwater Management System Design
}

\author{
Aaron C. Farrell, Ronald B. Scheckenberger and Raymond T. Guther
}

Stormwater management systems for new urban development have been traditionally designed and analyzed with the aid of computer models employing design storm events [such as the Soil Conservation Service (SCS) temporal distribution], rather than continuous modeling using long term historical rainfall data and associated frequency analyses. It has generally been accepted that the latter method provides a more rigorous and realistic design; however, the differences in the results (i.e. designs) generated by the two methods have not typically been understood during the planning and design process. This chapter describes a case study in the Town of Milton (Sixteen Mile Creek Watershed) in which, based on a unique opportunity, both methods were applied in the analysis and preliminary design of end-of-pipe stormwater management facilities. The different flow and storage regimes generated by the alternate methods are highlighted, along with a number of modeling and physical factors which are considered to contribute to the differing results.

\subsection{Introduction}

Urbanization generally reduces opportunities for stormwater to infiltrate, thus increasing the volume and rate of stormwater runoff. This results in higher, more frequent peak flow rates from the developed area, leading to increased occurrences of flooding and erosion.

Farrell, A., R.B. Scheckenberger and R.T. Guther. 2001. "A Case in Support of Continuous Modeling for Stormwater Management System Design." Journal of Water Management Modeling R207-07. doi: 10.14796/JWMM.R207-07.

(C) CHI 2001 www.chijournal.org ISSN: 2292-6062 (Formerly in Models and applications to Urban Water Systems. ISBN: 0-9683681-4-X) 
Urbanization also typically degrades water quality (i.e. high loading of pollutants such as nutrients, sediments, organic compounds and heavy metals). Without proper stormwater management, urbanization may increase erosion and flooding potential in downstream watercourses, potentially incurring damage to properties, as well as degrading water quality.

Two analytical methods for determining catchment flow response are available to engineers: single event (design storms) or continuous modeling (observed record). Once flow response to rainfall input is defined, under existing and future land use conditions, stormwater management systems can be designed. Continuous simulation has generally been accepted as the more rigorous and accurate of the two methods (James, 1994a; 1994b). The influence of the two analytical techniques on stormwater management system designs though has rarely been documented.

\subsubsection{Problem Statement}

A Subwatershed Planning Study was prepared to guide the Municipality (Town of Milton) and responsible agencies in the management of land use change through the establishment of environmental management strategies for the existing developed areas, non-developing areas, and developing areas within the study area (Philips, 2000). Extensive hydrologic modeling and analysis was completed as part of the Subwatershed Planning Study in support of appropriate stormwater and environmental management techniques. Given a tight time frame to provide technical and environmental input to a concurrent land use planning process (Secondary Plan), it initially became necessary to use a simplified analysis and design approach. To this end, an initial set of stormwater management system designs was derived using a design storm approach $(12 \mathrm{~h}$ $\mathrm{SCS}$ design events with return periods from 2 to $100 \mathrm{y}$ ). This enabled the design team to provide general guidelines for stormwater management systems at an early stage in the project. During the balance of the Subwatershed Planning Study, the stormwater management systems were designed using a continuous modeling and frequency analysis approach, to verify and assess the previous recommendations. This project provided a unique opportunity to compare designs for different analytical techniques, namely the traditional design method (SCS design event modeling) and the more modern continuous modeling. Understanding the significance of the differences, the causative factors and the potential impact on management system designs are all considered important. 


\subsubsection{Study Area}

The Sixteen Mile Creek Watershed

The Sixteen Mile Creek Watershed (see Figure 7.1), located in Southern Ontario, receives drainage from four municipalities including: Milton, Halton Hills, Oakville and Mississauga. The watershed measures approximately $380 \mathrm{~km}^{2}$ and $7000 \mathrm{~m}$ in length. Planned urban expansion within the Region of Halton (Milton, Oakville and Halton Hills) was the impetus to initiate a Watershed Planning Study (completed in 1996 by Gore and Storrie, and Ecoplans Ltd.) and a subsequent Subwatershed Planning Study, which encompasses two of the nine subwatershed units.

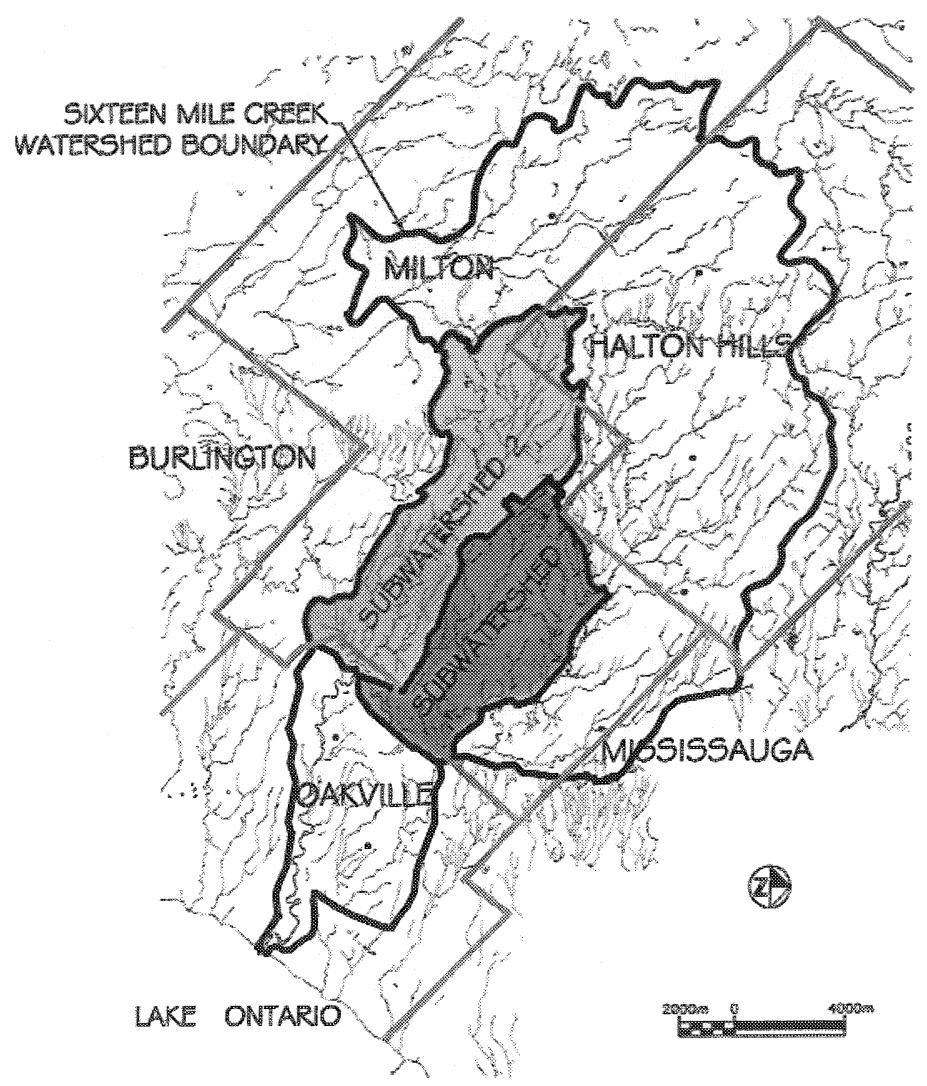

Figure 7.1 Sixteen Mile Creek watershed. 
Subwatershed Planning Study

Subwatershed Areas 2 and 7 located within the Town of Milton, have been proposed for significant urban development within the next 10 to $25 \mathrm{y}$. These subwatershed areas encompass approximately $98.7 \mathrm{~km}^{2}$ within which 33.3 $\mathrm{km}^{2}$ of development is proposed (see Figure 7.2). This would result in a net increase of approximately $200 \%$ in the size of the current community. In order to facilitate this development in accordance with current municipal, provincial and federal planning processes and policies, a Subwatershed Planning Study was initiated in the summer of 1998 and completed in early 2000.

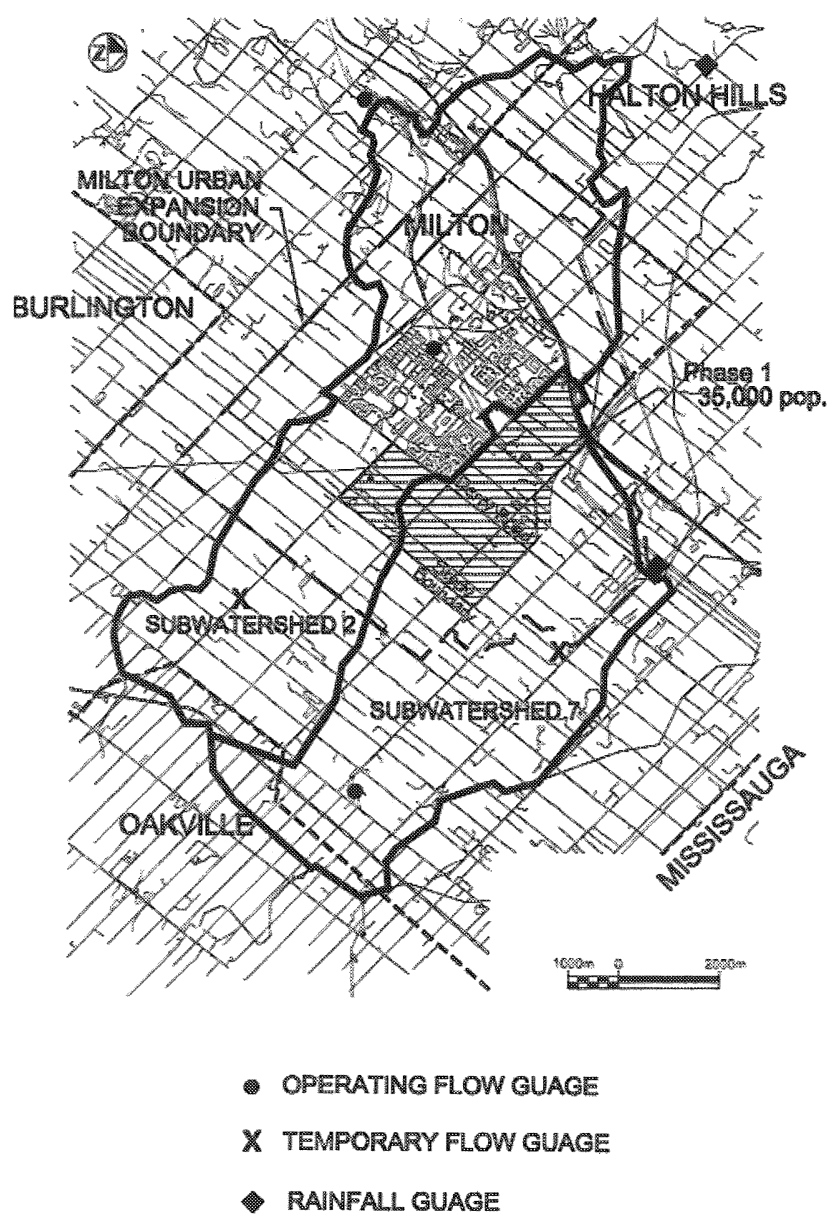

Figure 7.2 Proposed Milton urban expansion boundary (subwatersheds 2 and 7). 


\section{Phase 1 Study Area}

The first phase of the proposed development (referred to as the Phase 1 Area) encompasses an area of approximately 960 ha $\left(9.6 \mathrm{~km}^{2}\right)$, representing an increase in population of approximately 39,000. The proposed development consists of:

- residential $(64 \%)$

- park \& open space (25\%)

- employment land (commercial/industrial) (4\%)

- institutional (3\%)

- business park (2\%)

- $\operatorname{commercial}(2 \%)$

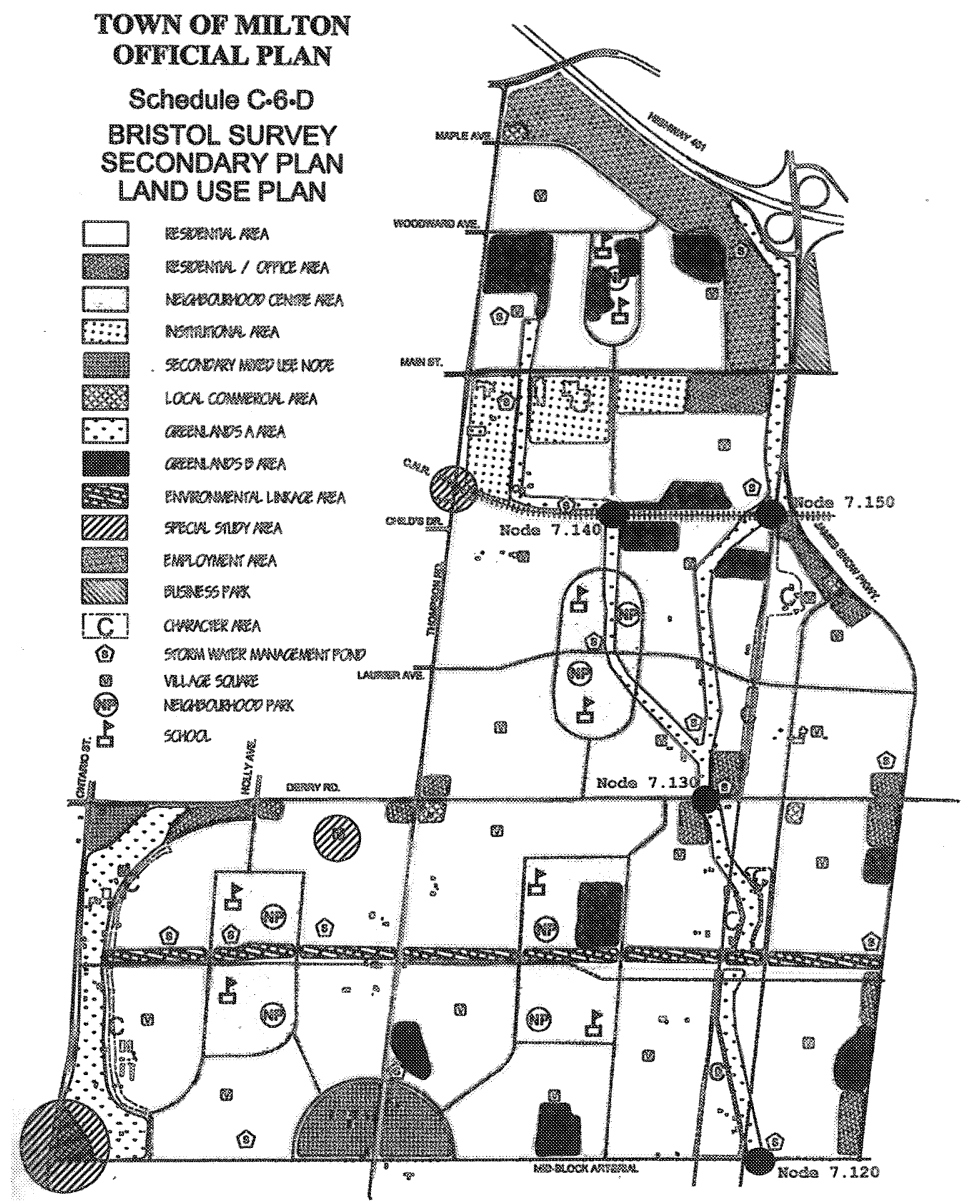

Figure 7.3 Conceptual plan of Phase 1 study area. 
The land use concept plan for the Phase 1 Area (see Figure 7.3) includes thirteen stormwater management facilities to address flood and erosion control and stormwater quality management.

\subsection{Analytical Approach}

\subsubsection{Previous Hydrologic Modeling}

The Sixteen Mile Creek watershed was previously modeled using the QUALHYMO program (Rowney and MacRae, 1991a, 1991b), as part of a previous Watershed Planning initiative (Gore and Storrie and Ecoplans Ltd., February 1996). The QUALHYMO model is capable of continuous simulation of hydrologic processes including snow accumulation and melting processes. The original model was calibrated to average daily flows at the two long-term stream flow gage locations within the watershed (see Figure 7.1). Additional simulations were performed for the $12 \mathrm{~h}$ Soil Conservation Service (Type II) design events using the calibrated QUALHYMO model to predict return period flood potential. The modeled watershed and subwatershed response obtained using the QUALHYMO model, particularly for design event simulation, was used as a comparative tool to validate the calibration of the Hydrologic Simulation Program Fortran (HSP-F) model developed for the Subwatershed Planning Study.

\subsubsection{Study Modeling Approach}

For the purposes of the Subwatershed Planning Study, HSP-F Version 11 was used. Although more complex than QUALHYMO, HSP-F's capability for full continuous simulation, including snow accumulation and melt was considered important to properly replicate these processes.

The calibration and verification procedure for the HSP-F model included the following:

- calibration and verification to the daily average flows used for the original QUALHYMO model (period of record 1969 - 1975),

- calibration to the peak flows and volumes, as generated by the $12 \mathrm{~h} \mathrm{SCS} \mathrm{design} \mathrm{storm} \mathrm{distribution,} \mathrm{as} \mathrm{per} \mathrm{the} \mathrm{original} \mathrm{QUALHYMO}$ model,

- calibration and verification to recorded hourly flows within tributary (upper) subwatersheds,

- calibration and verification to flow gages, temporarily located within the Phase 1 study area, during the course of the study, and 
- verification of snow accumulation and melt parameters to snowpack data provided by Conservation Halton.

The preparation and calibration of the HSP-F model was complicated by the following factors:

- presence of swamps, wetlands, and operated reservoirs within the upper subwatersheds,

- water-taking from the system for various purposes (i.e. agricultural use and golf course irrigation),

- need to account for major and minor flow dynamics (i.e. overland flow and sewer flow respectively), within certain basins of the Phase 1 study area, and

- influence of snow accumulation and melt, which introduced additional calibration parameters and associated sensitivity to the time step of the temperature data (i.e. daily vs. hourly).

Swamps and wetlands were simulated by increasing the lower and upper zone storage parameters (LZSN and UZSN respectively) within the subcatchments. Separation of major and minor flows was simulated using a rating curve approach, which was developed based upon the estimated sewer capacity.

The model for the Sixteen Mile Creek watershed consisted of 84 subcatchments, ranging in size from 17.4 ha to 7870 ha, featuring a higher level of detail and discretization within the Phase 1 study area. The Phase 1 study area was discretized into 20 subcatchments for the simulation and design.

\subsection{Stormwater Management System Design}

\subsubsection{Design Event Approach}

As noted in Section 7.1.1, the study timing requirements, specifically the Secondary Land Use Planning Study, were such that an initial set of stormwater management facility designs were needed quickly for planning and design purposes. These were initially derived using the $12 \mathrm{~h} \mathrm{SCS} \mathrm{design} \mathrm{events} \mathrm{in} \mathrm{order}$ to obtain approximate sizes of the proposed facilities and outlet configurations (including preliminary costs).

\section{HSP-F Design Event Simulation}

Soil moisture within HSP-F is accounted for in the water budget within upper and lower zones. The approach to calibrating the model in this study involved setting the initial values for storage, within the upper and lower zones, to 1.25 
times the nominal value (i.e. for the $12 \mathrm{~h} \mathrm{SCS} \mathrm{event)} \mathrm{to} \mathrm{account} \mathrm{for} \mathrm{Type} \mathrm{II}$ antecedent moisture conditions (AMC).

Meteorological data for temperature, wind, solar radiation, dewpoint, and evapotranspiration were abstracted from typical summer conditions; the same data were used for each simulation. This approach was considered reasonable, as the $12 \mathrm{~h} \mathrm{SCS}$ events were considered comparable to intense thunderstorms, which typically occur during the summer.

\section{SWM Facility Design Philosophy}

The proposed stormwater management facilities were designed using a "uniform" unbiased approach, in which stormwater management facility volume varied directly with the impervious area draining to the facility, and discharge from the facility varied directly with the total area draining to the facility. That is to say, the design approach did not consider optimizing the performance of the various facilities, to refine or reduce storage based on local targets. All of the proposed stormwater management facilities, throughout the Phase 1 study area, were sized using this approach. Refinement of facility volumes was considered beyond the scope of the Subwatershed Planning Study, more appropriately undertaken once land use is refined at the subdivision design stage.

\subsubsection{Continuous Modeling Approach}

The Subwatershed Planning Study process provided an opportunity to design a more detailed set of stormwater management facilities, based upon a $34 \mathrm{y}$ continuous simulation. Meteorological data for the analysis were obtained from the Royal Botanical Gardens AES gage in Hamilton, Ontario (ca. $20 \mathrm{~km}$ from of the study area). The time series of meteorological input included temperature data, which was used for simulating snow accumulation and melt.

Similar to the design event approach, a uniform facility design standard was applied throughout study area, in which facility storage varied directly with impervious area draining to the facility, and discharge from the facility varied directly with total area draining to the facility.

The unitary storage and discharge criteria developed for the continuous modeling approach were different from those developed for the design event approach. Figure 7.4 compares the rating curves for a facility designed for a specific location within the subwatershed, based on the design event vs. continuous modeling approach. The most significant differences between the two designs are the higher rate of storage versus outflow and lower overall storage obtained using the continuous modeling approach. 


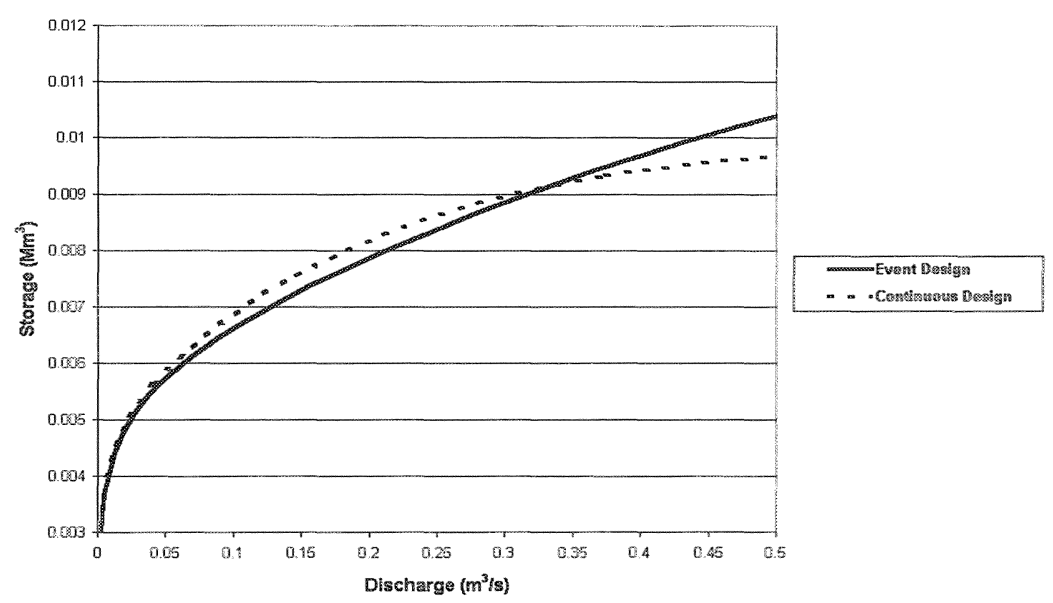

Figure 7.4 Rating curves for typical SWM facility.

\subsection{Evaluation and Assessment}

Each set of stormwater management facility designs was evaluated using the following criteria:

- post-development to pre-development control for $12 \mathrm{~h} \mathrm{SCS} \mathrm{event}$ simulation,

- post-development to pre-development control for continuous modeling and frequency analysis, and

- effect on base flow and erosion control based on duration analysis.

\subsubsection{Target Flows}

Targets for each design approach were defined based on modeling existing land use conditions, using rainfall input appropriate for the design approach. The existing conditions model for the Phase 1 study area was developed to the same level of discretization as for the future conditions model, to ensure comparable results, and to eliminate modeling bias.

Four locations were identified as key points of comparison within the Phase 1 study area, namely (see Figure 7.3):

- west crossing at Canadian Pacific Railway (CPR) tracks (Node 7.140),

- east crossing at CPR tracks (Node 7.150), 
- Derry Road crossing (Node 7.130), and

- Phase 1 southeast boundary (Node 7.120).

The total drainage area to the Phase 1 southeast boundary node is expected to decrease under future conditions due to anticipated grading within the development area; drainage area to the remaining three nodes within the Phase 1 study area is expected to remain comparable between existing and future conditions.

\subsubsection{Design Event Results}

Both sets of stormwater management facility designs were evaluated using the 12 hour SCS design events. Table 7.1 summarizes the results at the key locations. The results at Derry Road (Node 7.130) are presented in Figure 7.5. The results indicate that both sets of facility designs would provide the required post-to-pre control based on a $12 \mathrm{~h} \mathrm{SCS}$ design event. The results also indicate that the facilities designed using the continuous modeling approach would overcontrol the peak runoff, compared to the facilities designed using the design event approach, particularly for more frequent events (i.e. 2 to $10 \mathrm{y}$ ).

Table 7.1 Stormwater management facility performance assessment, using design event rainfall - simulated peak flow $\left(\mathrm{m}^{3} / \mathrm{s}\right)$.

\begin{tabular}{|c|c|c|c|c|c|c|}
\hline \multirow{2}{*}{$\begin{array}{l}\text { Simulated } \\
\text { Conditions }\end{array}$} & \multicolumn{6}{|c|}{ Event Frequency (Years) } \\
\hline & 2 & 5 & 10 & 25 & 50 & 100 \\
\hline Node 7.140 & & & & & & \\
\hline Existing Land Use & 0.30 & 0.75 & 1.26 & 2.18 & 3.00 & 3.92 \\
\hline $\begin{array}{l}\text { Future Land Use - } \\
\text { Event Design }\end{array}$ & 0.31 & 0.77 & 1.15 & 1.74 & 2.24 & 2.98 \\
\hline $\begin{array}{l}\text { Future Land Use - } \\
\text { Continuous Design } \\
\text { Node } 7.150\end{array}$ & 0.12 & 0.41 & 0.69 & 1.15 & 2.02 & 3.04 \\
\hline Existing Land Use & 0.26 & 0.62 & 1.02 & 1.73 & 2.37 & 3.10 \\
\hline $\begin{array}{l}\text { Future Land Use - } \\
\text { Event Design }\end{array}$ & 0.19 & 0.61 & 0.93 & 1.45 & 2.00 & 2.53 \\
\hline $\begin{array}{l}\text { Future Land Use - } \\
\text { Continuous Design } \\
\text { Node } 7.130\end{array}$ & 0.10 & 0.36 & 0.59 & 0.97 & 1.66 & 2.49 \\
\hline Existing Land Use & 0.75 & 1.78 & 2.90 & 4.86 & 6.75 & 8.97 \\
\hline $\begin{array}{l}\text { Future Land Use - } \\
\text { Event Design }\end{array}$ & 0.61 & 1.70 & 2.69 & 4.12 & 5.47 & 7.43 \\
\hline $\begin{array}{l}\text { Future Land Use - } \\
\text { Continuous Design } \\
\text { Node } 7.120\end{array}$ & 0.32 & 1.11 & 1.85 & 3.05 & 4.83 & 7.72 \\
\hline Existing Land Use & 0.82 & 1.80 & 3.02 & 5.33 & 7.50 & 9.99 \\
\hline $\begin{array}{l}\text { Future Land Use - } \\
\text { Event Design }\end{array}$ & 0.77 & 2.07 & 3.24 & 5.06 & 6.60 & 8.70 \\
\hline $\begin{array}{l}\text { Future Land Use - } \\
\text { Continuous Design }\end{array}$ & 0.42 & 1.41 & 2.35 & 3.83 & 5.75 & 8.92 \\
\hline
\end{tabular}


Although the event based technique provides a means for assessment of flood impact performance, it does not allow for easy or effective assessment of erosion impact performance.

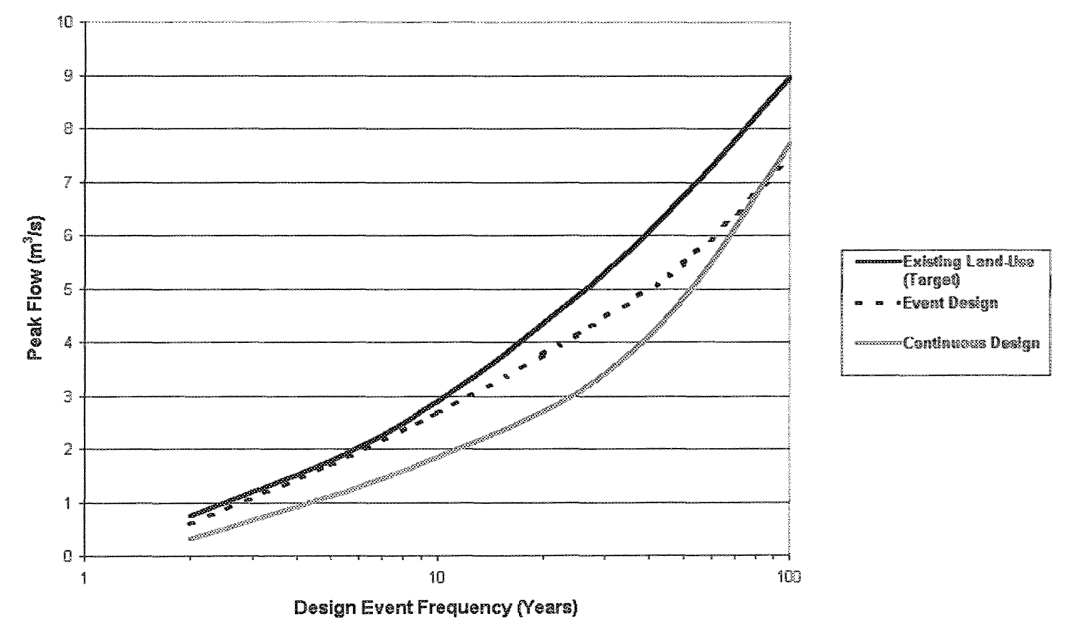

Figure 7.5 Stormwater management facility performance comparison using design event simulations.

\subsubsection{Continuous Modeling Results}

The two sets of stormwater management facility designs were also analyzed using the 34 year record $(1962$ - 1995) and continuous modeling, frequency analysis and duration analysis.

\section{Flood Control Assessment}

The statistical results for the existing land use conditions modeling suggest that the Log Pearson Type III distribution is most applicable in this study for frequency analysis, based upon Ontario - Ministry of Natural Resources standards (MNR, 1986). Table 7.2 summarizes the results of frequency analysis performed for the continuous modeling of existing conditions and future land use with stormwater management facilities based on the two design approaches. Figure 7.6 presents the results at Derry Road. The results indicate that the facilities designed based upon the $12 \mathrm{~h} \mathrm{SCS}$ event criteria would fail to provide sufficient post-to-pre control for more frequent events. 
Table 7.2 Stormwater management facility performance assessment using continuous modeling - simulated peak flow $\left(\mathrm{m}^{3} / \mathrm{s}\right)$.

\begin{tabular}{|c|c|c|c|c|c|c|c|c|}
\hline \multirow{2}{*}{$\begin{array}{l}\text { Simulated } \\
\text { Conditions }\end{array}$} & \multicolumn{8}{|c|}{ Event Frequency (Years) } \\
\hline & 1.05 & 1.25 & 2 & 5 & 10 & 20 & 50 & 100 \\
\hline \multicolumn{9}{|l|}{ Node 7.140} \\
\hline Existing Land Use & 0.088 & 0.200 & 0.430 & 0.860 & 1.20 & 1.55 & 2.05 & 2.45 \\
\hline $\begin{array}{l}\text { Future Land Use - } \\
\text { Event Design }\end{array}$ & 0.170 & 0.310 & 0.550 & 0.960 & 1.26 & 1.58 & 2.02 & 2.37 \\
\hline $\begin{array}{l}\text { Future Land Use - } \\
\text { Continuous Design }\end{array}$ & 0.079 & 0.180 & 0.380 & 0.770 & 1.09 & 1.43 & 1.91 & 2.30 \\
\hline \multicolumn{9}{|l|}{ Node 7.150} \\
\hline Existing Land Use & 0.075 & 0.170 & 0.360 & 0.710 & 0.980 & 1.27 & 1.68 & 2.00 \\
\hline $\begin{array}{l}\text { Future Land Use - } \\
\text { Event Design }\end{array}$ & 0.110 & 0.220 & 0.430 & 0.810 & 1.10 & 1.41 & 1.84 & 2.20 \\
\hline $\begin{array}{l}\text { Future Land Use - } \\
\text { Continuous Design }\end{array}$ & 0.062 & 0.150 & 0.320 & 0.670 & 0.950 & 1.25 & 1.69 & 2.04 \\
\hline \multicolumn{9}{|l|}{ Node 7.130} \\
\hline Existing Land Use & 0.230 & 0.510 & 1.10 & 2.21 & 3.11 & 4.07 & 5.43 & 6.53 \\
\hline $\begin{array}{l}\text { Future Land Use - } \\
\text { Event Design }\end{array}$ & 0.350 & 0.690 & 1.32 & 2.39 & 3.22 & 4.07 & 5.25 & 6.19 \\
\hline $\begin{array}{l}\text { Future Land Use - } \\
\text { Continuous Design }\end{array}$ & 0.200 & 0.480 & 1.02 & 2.08 & 2.93 & 3.84 & 5.14 & 6.18 \\
\hline Node 7.120 & & & & & & & & \\
\hline Existing Land Use & 0.260 & 0.620 & 1.38 & 2.81 & 3.97 & 5.20 & 6.93 & 8.32 \\
\hline $\begin{array}{l}\text { Future Land Use - } \\
\text { Event Design }\end{array}$ & 0.440 & 0.860 & 1.63 & 2.95 & 3.95 & 5.00 & 6.46 & 7.62 \\
\hline $\begin{array}{l}\text { Future Land Use - } \\
\text { Continuous Design }\end{array}$ & 0.260 & 0.600 & 1.30 & 2.62 & 3.69 & 4.82 & 6.41 & 7.69 \\
\hline
\end{tabular}
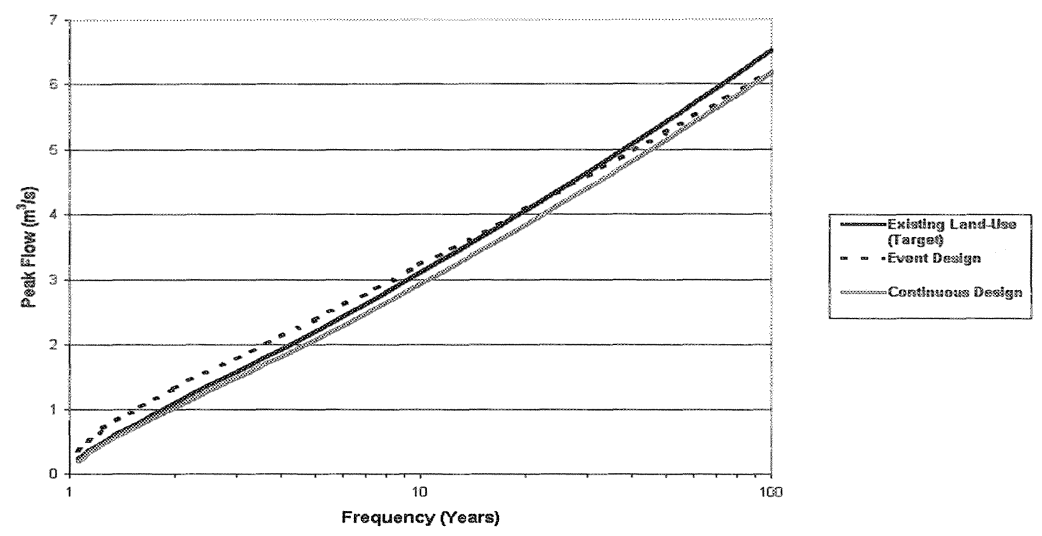

Figure 7.6 Stormwater management facility performance comparison using continuous simulation (frequency analysis). 


\section{Duration Analysis/Erosion Assessment}

Duration analyses were performed based on continuous modeling in order to evaluate the effect of the proposed stormwater management facility designs on baseflow and erosion control. Figures $7.7 \mathrm{a}$ and $7.7 \mathrm{~b}$ summarize the results of the proposed facility designs on baseflow and erosion control. As Figure 7.7a indicates, baseflow duration would increase with future land use under either design approach. This would enhance the sustainability of fish habitat within the study area. The system tends to perform better (i.e. higher baseflow in

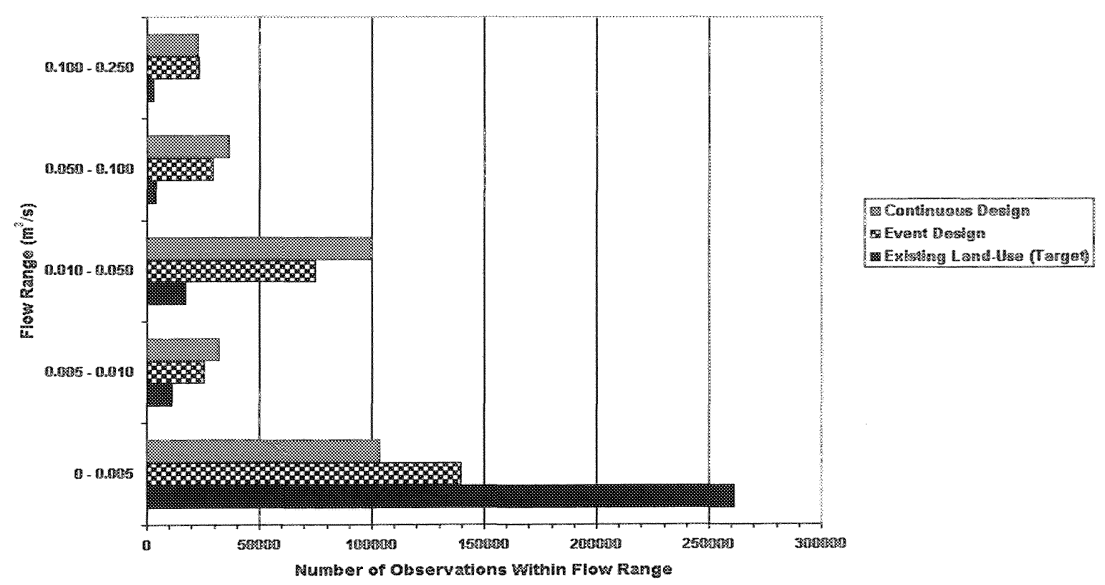

Figure 7.7a Comparison of flow distributions for baseflow ranges

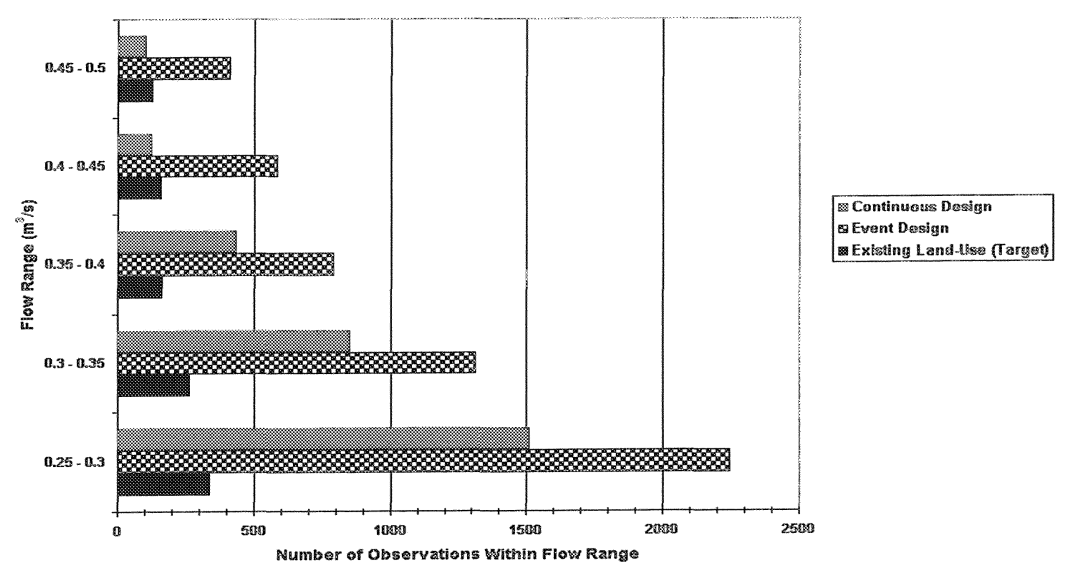

Figure 7.7b Comparison of flow distributions for erosive flow ranges 
critical range) for the case where facilities are designed using continuous simulation. Figure $7.7 \mathrm{~b}$, however, indicates that the facilities designed by continuous modeling would provide superior erosion control than the facilities designed by the $12 \mathrm{~h}$ SCS events.

\subsection{Discussion}

From the foregoing, it is evident that the design of stormwater management facilities using continuous modeling provides superior performance in terms of erosion and flood control. However, the reasons for the differences have yet to be discussed. The following describes the differences in the two design methodologies, which account, in part, for the differences in the results obtained from the two approaches.

\subsubsection{Soil Moisture Conditions}

One of the most significant differences between the two design methods is the antecedent soil moisture conditions at the time of peak runoff events. As previously noted, soil moisture is simulated in HSP-F as storage within the upper and lower zones of the soil. Figure 7.8 compares the upper and lower zone moisture content for the calibrated HSP-F model, for a "typical" year (1971), with the values used for the design event simulation. The following is evident:

- soil moisture content simulated by continuous modeling varies on a seasonal basis; soil moisture content is highest during the spring months (March and April) and lowest during the summer months (July and August), only rising in response to intense summer thunderstorms; and

- the initial values of soil moisture assumed for the 12 hour SCS event simulation is greater than the simulated values for the summer months during which runoff from intense storm events would occur.

From the foregoing assessment, it is clear that the higher soil moisture assumed using the design event approach over-estimated the runoff which would occur under existing land use conditions during intense storms.

\subsubsection{Timing of Annual Maxima (Peak Flows)}

The results for the continuous modeling were assessed for the timing of annual maximum flows. Figure 7.9 compares when actual and simulated annual peak flows occur, for existing land use conditions. The results suggest a reasonable 


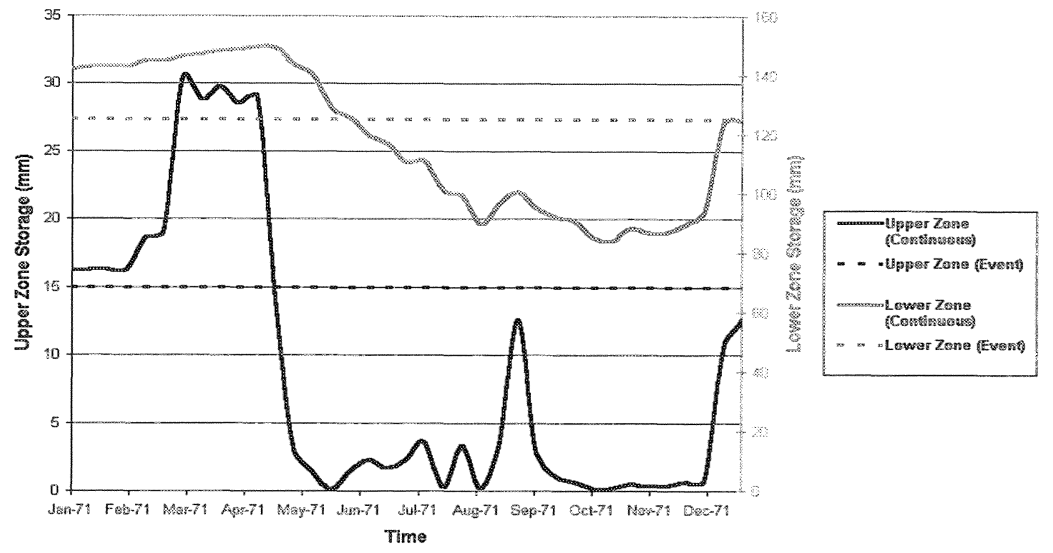

Figure 7.8 Seasonal variation of simulated soil zone moisture content for calibrated model.

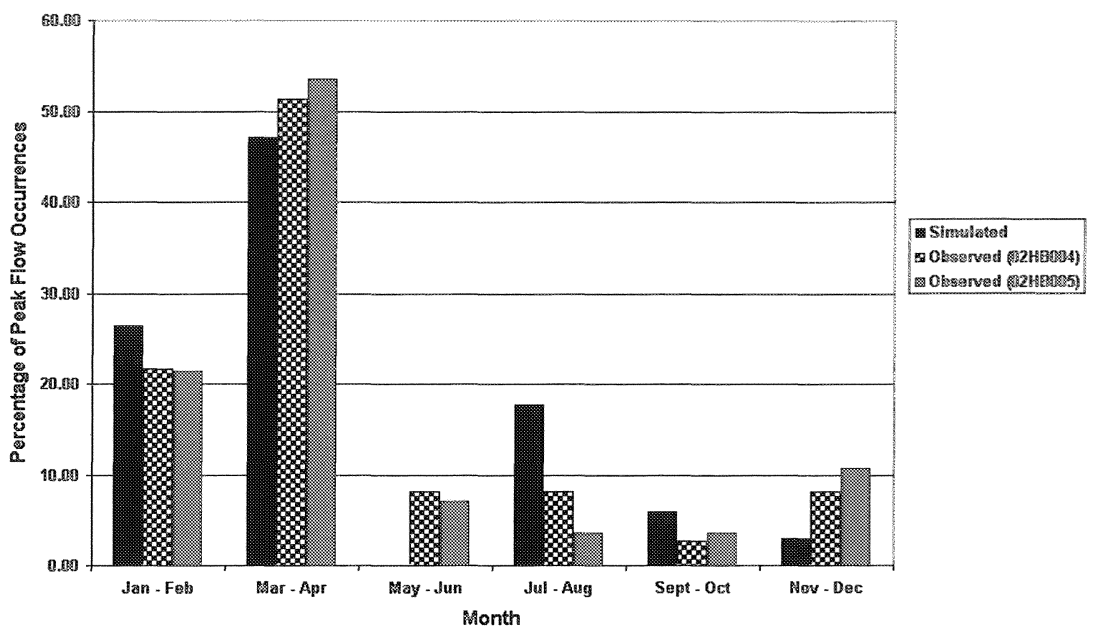

Figure 7.9 Monthly distribution of simulated and observed annual peak flows for existing land use conditions.

correlation for existing land use conditions, whereby the annual maximum flow typically occurs during the months of March or April.

The timing for simulated annual peak flows, for controlled and uncontrolled future land use conditions, are compared with simulated annual peak flows for existing conditions in Figure 7.10. The results indicate the following: 
- annual peak flows for existing land use conditions are typically associated with spring freshet during the months of March and April;

- annual peak flows for future land use uncontrolled conditions are typically associated with intense summer thunderstorms during the months of July and August; and

- annual peak flows for future controlled conditions are more closely associated with the occurrence of the annual peaks for existing conditions than for future uncontrolled conditions.

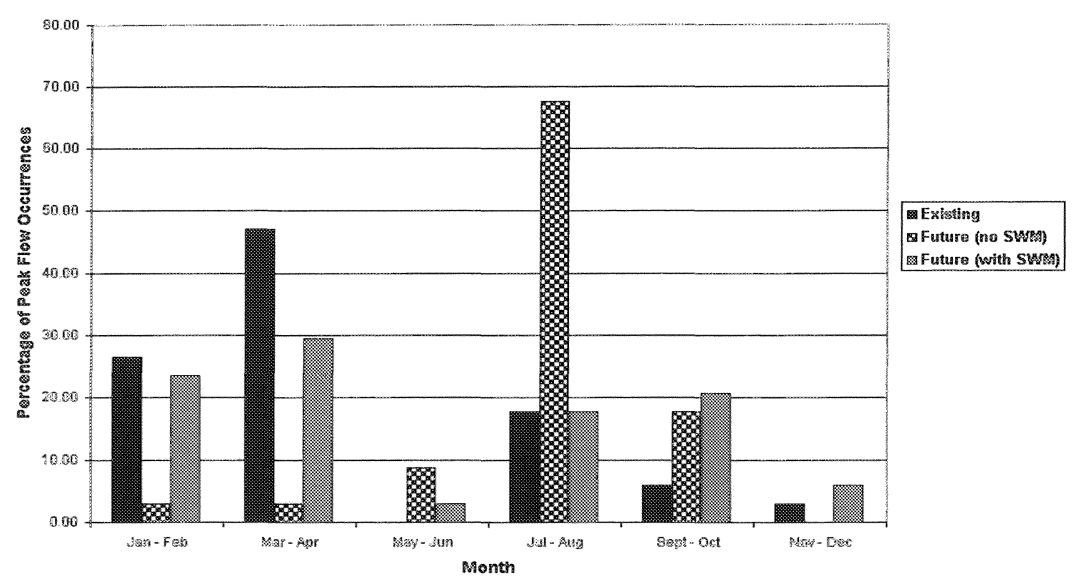

Figure 7.10 Monthly distribution of simulated annual peak flows (1962-1995).

\subsection{Conclusions}

This unique opportunity to compare stormwater management design and performance suggests that the two methods of stormwater management system analysis and design provide different results. The differences can be attributed, in part, to the soil moisture accounting, which was lower than expected for summer storm events. The design event approach tends to overestimate antecedent moisture conditions for existing land use conditions, and the subsequent peak runoff which defines the target flows. Consequently, stormwater management systems designed based upon the design event approach do not provide sufficient control for the more frequent storm events. Furthermore, the design event approach does not provide an effective means for designing erosion control practices. 
Snow accumulation and melt is critical in system design. Although the future uncontrolled peak discharge is typically associated with the more intense storm events, existing (target) and future controlled peak discharge typically results from the spring freshet. These processes should be considered in the design of stormwater management systems. Results from the Subwatershed Planning Study also indicated that the temperature data associated with these processes should be provided in small time intervals (i.e. $1 \mathrm{~h}$ or less) for more realistic simulation results.

The stormwater management system designed using the continuous modeling approach generally resulted in less overall storage than the system designed using the design event approach. Nevertheless, continuous modeling requires substantial amounts of reliable data for proper calibration and simulation, which may limit its application to system design in smaller scale applications.

The significance of scale can also be influential in establishing design targets. Initial flows for existing land use conditions were obtained from a "coarse" model of five subcatchments through the Phase 1 study area. This coarse model produced higher peak flows than were obtained from the more refined or discrete model of twenty subcatchments. Modeling bias associated with scale (i.e. size of subarea) should be understood.

While the results of this case study clearly demonstrate that the continuous modeling approach was most appropriate for the Sixteen Mile Creek, Areas 2 and 7 Subwatershed Planning Study, the design event approach would be considered appropriate for smaller catchments and local stormwater management system design verification.

\section{References}

Bicknell, B.R., Imhoff, J. C., Kittle J. L. and A.S. Donigian, September 1996. Hydrological Simulation Program - Fortran (HSP-F) User's Manual for Release 11. U.S. EPA

Gore and Storrie, and Ecoplans Ltd., February 1996, Sixteen Mile Creek Watershed Plan. Prepared in support of the Halton Urban Structure Plan

James, W., 1994. Rules for Responsible Modelling, Computational Hydraulics International, Guelph, Ontario

James, W., 1994. On Reasons Why Traditional Single-Valued, Single-Event Hydrology (Typical Design Storm Methodology) Has Become Simple-Minded, Dishonest and Unethical. Urban Hydrology \& Hydraulics Workshop. US Army Corps of Engineers Hydrologic Engineering Center, Davis, California, Sept. 13-15.

Macaulay Shiomi Howson, December 1998, Secondary Plan (Official Plan Amendment \#3) Town of Milton, South-East Planning District 
Ontario Ministry of Natural Resources, 1986. Flood Plain Management in Ontario, Technical Guidelines, ISBN 0-7729-1029-4

Philips Planning and Engineering Limited, January 2000, Sixteen Mile Creek Subwatershed Areas 2 and 7 Planning Study -General Report

Rowney, A. C. and C. R. MacRae, 1991a. QUALHYMO User Manual - Release 2.1, Royal Military College of Canada, Kingston, Ontario

Rowney, A. C. and C. R. MacRae, 1991b. QUALHYMO Technical Reference Manual - Release 2.1, Royal Military College of Canada, Kingston, Ontario

Soil Conservation Service, 1972. National Engineering Handbook, section 4 Hydrology, U.S. Department of Agriculture, Washington D.C. 